\title{
Gene expression in elongating and gastrulating embryos from ruminants
}

\author{
I Hue, SA Degrelle, E Campion and J-P Renard \\ INRA, UMR 1198; ENVA; CNRS, FRE 2857, Biologie du Développement et Reproduction, Jouy en \\ Josas, F-78350, France
}

In ruminants, more than $30 \%$ of the embryonic losses observed after artificial insemination (Al) have an early origin, coincident with a marked elongation of the trophoblast which occurs before implantation. Several observations provide clear evidence that early elongation of the conceptus relies on cell multiplication, cell growth and cell shape remodeling. Recent results indicating an intense multiplication of a non-fully differentiated trophoblast, which still expresses some epiblast genes, has to be considered at the onset of elongation. It has also been shown in the last two years that general metabolism and protein trafficking are characteristic of the onset of elongation whereas cellular interactions, cell to cell signaling and cell adhesion become predominant at the end of elongation. Accordingly, expression of most of the single genes identified so far increases during elongation and is related to the establishment of embryo-maternal exchanges before implantation. However, not much is known of what controls the induction of the elongation process or the coordinated development of the embryonic and extra-embryonic tissues. This review highlights new information on this developmental phase and summarizes the views on the complex cross-talk among molecules which might govern conceptus development and lead to successful implantation.

\section{Introduction}

After fertilisation and cleavage, the mammalian embryo reaches the blastocyst stage. This stage occurs after in vivo or in vitro development and is characterised by the morphological distinction between two cell types: the inner cell mass (or ICM) and the trophectoderm, even though molecular distinctions between these lineages appear earlier (Rossant 2004). In ruminants, the blastocyst is a sphere of $150-200 \mu \mathrm{m}$ in diameter which contains approximately $250-300$ cells (8 days after mating or insemination). A few days later, the sphere has enlarged, the number of cells is 10 times higher and the blastocyst has evolved to an ovoid shape (Day 11 in sheep, Day 12 in cows). According to Chang (1952) the ICM evolves into a germinal disc and the endoderm cells underlying the disc migrate under the trophectoderm to form an extra-embryonic endoderm layer. On Day 12 in sheep and Day 14 in cows, the blastocyst has a tubular shape, and the germinal disc is a true embryonic disc that is flat and open to the uterine environment since the trophoblast layer (called polar trophoblast or Rauber's layer) which covers the ICM 
until this stage has disappeared. Subsequently, the mural trophoblast lineage further elongates and gives rise to a filamentous-shaped conceptus (Day 14 in sheep, Day 16 to 18 in cows) composed of differentiated embryonic and extra-embryonic tissues. The extra-embryonic tissues include the chorion, formed by fusion of trophectoderm with migrating extra-embryonic mesoderm, and the growing yolk sac composed of extra-embryonic endoderm and mesoderm. Growth and differentiation processes of embryonic and extra-embryonic lineages are referred to as gastrulation and elongation, respectively. Finally, the trophoblast forms loose cellular contacts with the endometrial layer of the uterus, which marks the onset of implantation (Day 15 in sheep, Day 19 in cows; Guillomot 1995).

This review focuses on the process of conceptus elongation without comments on trophoblast lineage differentiation or implantation which were reviewed recently (Roberts et al. 2004; Spencer \& Bazer 2004). We will concentrate on recent molecular data and comment on elongation models to gain insights into this complex process, mostly studied as an essential step in establishing functional embryo-maternal communications (Wolf et al. 2003; Imakawa et al. 2004; Klein et al. 2006). Maternal recognition of pregnancy is indeed essential for the uterus to switch from a cyclic to a pregnant state as underlined by the high rate of embryonic loss before implantation (Anderson 1978; Dunne et al. 2000; Goff 2002). This review will mainly describe gene expression patterns in ruminants, but occasionally comments on results obtained from studies of porcine conceptuses which also elongate and gastrulate before implantation.

\section{Elongation and extra-embryonic development}

Elongation defines the exponential growth of bovine, ovine and porcine blastocyst which occurs before implantation, with rapid evolution in their shapes from spherical to ovoid, tubular and finally filamentous forms (see Fig. 1). Though simple in its description, elongation is a complex process which does not have a clear starting point. Depending on species, elongation starts when conceptuses are at a spherical to slightly ovoid stage (pig) or an ovoid to slightly tubular stage (sheep, cow), on Day 11 (pig, sheep) or Day 12 (cow) post-insemination and at diverging blastocyst sizes: 1 to $2 \mathrm{~mm}$ (sheep, cow) or 9 to $10 \mathrm{~mm}$ (pig). It seems that these parameters (Wintenberger-Torres \& Flechon 1974; Geisert et al. 1982; Betteridge \& Flechon 1988), though extremely useful when collecting the embryos, are not adequate to establish a clear starting point to understand it at the molecular level. Therefore, we define the 150-200 $\mu \mathrm{m}$ freshly hatched blastocyst as the developmental stage for beginning elongation, the spherical-ovoid transition as the induction phase of elongation, the tubular-filamentous transition as a step of elongation maintenance and implanting stages as a phase of elongation arrest.

When starting elongation at the early blastocyst stage, cell proliferation likely constitutes the initiating event of the process. The clear increase in cell numbers initially observed between spherical and ovoid stages (Chang 1952; Wintenberger-Torres \& Flechon 1974) has been confirmed using several molecular approaches. Analysing the transition in development of bovine blastocysts between Days 7 and 14, Ushizawa et al. (2004) identified 680 genes for which expression increased and 26 genes that were down-regulated including those encoding for oncogenes, tumor suppression, cell cycle control and apoptosis (see Fig. 1). Similarly, cell cycle and cell proliferation related genes represented $29 \%$ of the annotated repertoire we established at the ovoid stage (Degrelle et al. 2005) while a small set of genes preferentially expressed at the ovoid stage included a marker of cell proliferation in human cancers (Nap1L1). However, since none of these transcripts has been localised in situ at spherical or ovoid stages, the molecular and cellular basis of this proliferation process remains poorly characterised. 


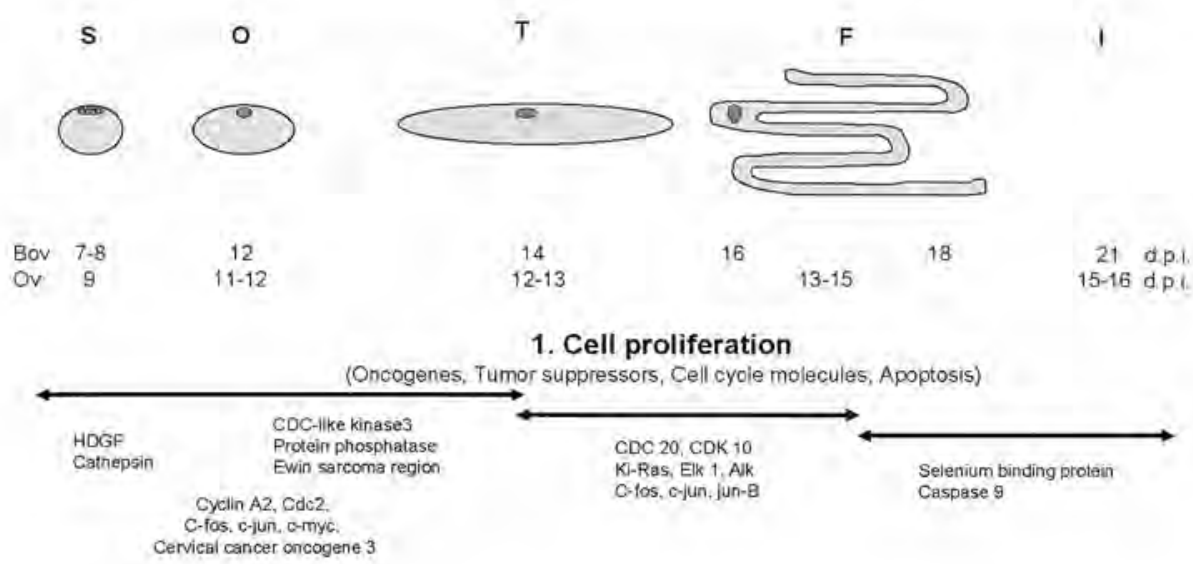

2. Cellular remodeling

Cytoskeleton, ECM related genes, Cell adhesion molecules

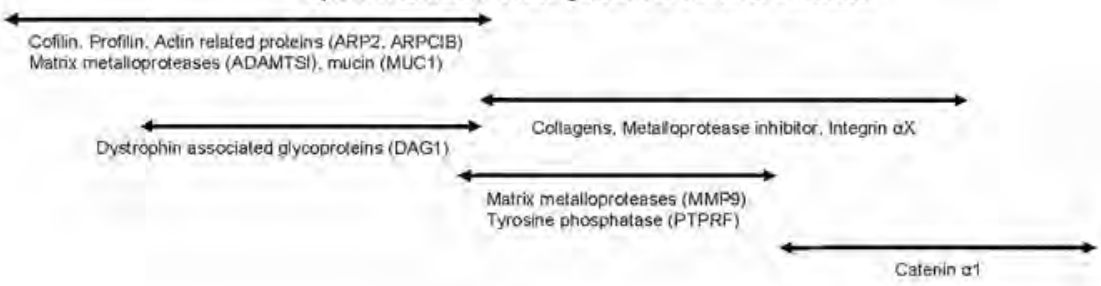

3. Protein trafficking

Synthesis, Transport Secretion

KOEL-R2, Rab1. Rab5C

Rab7. Clathrin polypeptide

\section{Cell signaling}

Cytokines, Growth factors, Growth factor binding proteins or receptors, $G$ proteins

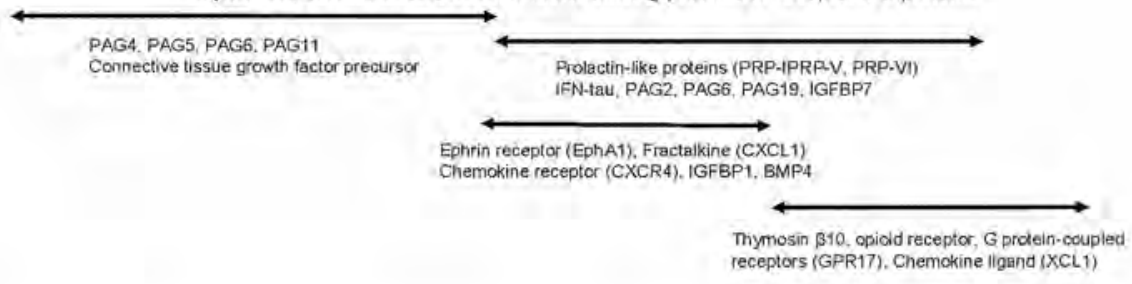

Fig. 1. Gene expression across elongation in ruminants. Some of the genes known to be expressed across elongation are named here together with the functions they relate to. Differential expression patterns are symbolised by horizontal arrows encompassing the appropriate stages: spherical (S), ovoid $(\mathrm{O})$, tubular $(\mathrm{T})$, filamentous $(\mathrm{F})$ or implanted (I). These sets of genes originate from the following reports: Ushizawa et al. 2004; Cammas et al. 2005; Degrelle et al. 2005; Xavier et al. 1997; ovoid cDNA library (I Hue \& SA Degrelle, unpublished observations). The conceptuses are schematically drawn according to their shape: light grey represents extra-embryonic tissues, dark grey; embryonic tissues. The developmental timing is scaled in days post insemination (or d.p.i) where day 0 marks the onset of oestrus. 
In addition to cell proliferation, the onset of elongation involves a cellular reorganisation based upon changes in cell morphology, density or migration. At the spherical stage, the trophectoderm is a layer of flattened cells and the endoderm cells which migrate out from the inner cell mass, start underlining the trophectoderm layer to give rise to the extra-embryonic endoderm. At the ovoid stage, these endoderm cells are flattened too, except at the level of the nucleus, whereas the trophectoderm cells are cuboidal and show numerous signs of phagocytosis (Betteridge \& Flechon 1988). In the pig, changes in the cellular organisation of both trophectoderm and endoderm layers have been put forward to explain the quick transitions observed in the size and shape of elongating conceptuses. Indeed, within a thin band of cells called "elongation zone", trophectoderm cells exhibited alterations of microfilaments and junctional complexes whereas endoderm cells formed numerous filopodia (Geisert et al. 1982). No similar observations of an "elongation zone" (surrounding the ICM and extending from the disc to distal ends of the conceptus) have been reported for ruminants but genes related to cell migration and cell remodelling have been identified in bovine and ovine conceptuses (Fig. 1). Similarly, genes involved in protein trafficking (which includes synthesis, secretion and transport) were highly expressed in sheep as previously revealed on transmission electron micrographs by the presence of rough endoplasmic reticulum or endocytic vesicles (Betteridge \& Flechon 1988). Cell differentiation and remodelling have also been explored at "late" stages of elongation and associated with implantation (Guillomot 1995; Spencer et al. 2004; Ushizawa et al. 2004; Cammas et al. 2005).

Last but not least, the elongation process has also been defined as an essential step in the establishment of pregnancy through an active cross-talk between the conceptus and the uterus well ahead of implantation. Cell signalling molecules have thus been identified accordingly (Fig. 1) and reported as increasingly expressed throughout the whole process or preferentially expressed at "late" elongated stages.

Despite the obvious roles of cell proliferation, cellular remodelling and cell signalling in the elongation process, most of the genes related to those functions were reported as "expressed in bovine or ovine elongating conceptuses" with no formal proof of a direct role in the induction, maintenance or arrest of the elongation process. In the absence of direct arguments through in vitro or in vivo knock-down approaches, it thus seems difficult to define the genes which really play the key roles in this complex process.

Recent molecular data based on the analysis of the transcriptome provided also genes or Expressed Sequence Tags (EST), the function of which is not elucidated so far. At first glance, this only lengthened the list of such genes we already had. For example, genes encoding Retinol Binding Proteins (RBP: Trout et al. 1991; Dore et al. 1994; Yelich et al. 1997a), Trophoblast Kunitz Domain Proteins (TKDP; MacLean et al. 2003; MacLean et al. 2004; Chakrabarty et al. 2006) or Pregnancy Associated Glycoproteins (PAG: Green et al. 2000; Hughes et al. 2003; Klisch et al. 2005) were isolated during elongation and further characterised as interesting gene families (TKDP, PAG) or important molecules for the elongation of porcine conceptuses (RBP). However their precise roles remain incompletely understood. Conversely, some of the genes identified through the use of transcriptomic approaches (arrays or SAGE: Serial Analysis of Gene Expression) brought novel perspectives on extra-embryonic development due to the functions they have outside of the elongation process. Among them: (i) an unusual chemokine (CX3CL1; sheep) which could mediate inflammatory reaction or cell adhesion; (ii) a Wnt inhibitor (Dickkopf1; cow) known to be expressed in embryonic tissues during gastrulation or in uterine tissues prior to implantation (Idkowiak et al. 2004; Bauersachs et al. 2006); and (iii) two developmental factors potentially regulated by estrogens: Stratifin and Midkine (pig; Blomberg et al. 2006). 


\section{Elongation and embryonic development}

Coincident with elongation, growth and differentiation of extra-embryonic tissues, embryonic development proceeds quickly from an inner cell mass, to a germinal disc and ultimately to an embryonic disc which undergoes progressive growth and differentiation (see Fig. 2). These developmental steps have been described extensively over the past decades (Chang 1952; Greenstein et al. 1958; Betteridge \& Flechon 1988; Vejlsted et al. 2006a), but there is little information on the molecular basis of gastrulation in ruminants or ungulates. Molecular markers have been isolated to characterise embryonic poles (anterior versus posterior), embryonic layers (ectoderm, endoderm or mesoderm) and specific structures appearing during gastrulation (e.g., primitive streak), but these markers have mostly been used to identify the stage of development of the embryonic disc. Expression patterns for goosecoid and brachyury were thus reported for ungulates using wholemount in situ hybridisation and used as early markers for the primitive endoderm or the mesoderm, respectively in order to stage the embryos (Meijer et al. 2000; van de Pavert et al. 2001; Hue et al, 2001), Recent studies using either RNA or antibodies as probes revealed additionally interesting specificities in the expression patterns of key gastrulation genes in ungulates as compared to their patterns in the mouse (Guillomot et al. 2004; Flechon et al. 2004; Degrelle et al. 2005; Vejlsted et al. 2005; Vejlsted et al. 2006b; Blomberg le et al. 2006). To our knowledge however, no study has been conducted in ruminants to analyse the interactions between embryonic and extra-embryonic tissues as recently documented in the mouse where reciprocal inductive interactions are involved in (i) defining the antero-posterior pattern of the embryo (Beck et al. 2002; Richardson et al. 2006) and (ii) preventing precocious differentiation of the extra-embryonic ectoderm (Guzman-Ayala et al. 2004).

Therefore, we decided to study these interactions by taking advantage of the ease of nonsurgical recovery of bovine conceptuses prior to implantation. We thus selected bovine conceptuses according to their size (ovoid: 1-20 mm, tubular: 50-60 mm, early filamentous: 100$150 \mathrm{~mm}$ ) and compared the gene expression profiles of each elongation stage (ovoid, tubular and filamentous) while screening a bovine array of about $10000 \mathrm{cDNA}$ (10K array). A hierarchical clustering based on a set of differentially expressed genes between ovoid, tubular and early filamentous conceptuses revealed two main gene clusters, as well as two main developmental groups (Fig. 3). A major difference appeared between the ovoid versus the tubular and filamentous stages which confirmed on a large repertoire (10K array) that gene expression profiles between tubular and early filamentous conceptuses were not statistically different, as initially observed (1K array; Degrelle et al. 2005). In addition to the differences in the size of the conceptus or the extra-embryonic layers formed at those 3 elongation stages, another important feature distinguished them. At both tubular and filamentous stages, the embryonic disc is flat with a clear antero-posterior axis, whereas at the ovoid stage the embryonic disc is a non polarised germinal disc. When related to these morphological observations, the two gene clusters suggest that the transcriptional pattern which distinguishes an ovoid stage from tubular and filamentous stages is, in fact, a pre-gastrulating versus a gastrulating signature. The identity of the genes within these 2 clusters needs now to be explored and understood in the light of embryonic-extra-embryonic interactions. However, the existence of these clusters already extends previous observations where some of the key genes for the embryonic-extra-embryonic interactions in the mouse have been identified in ruminant extra-embryonic tissues (furin or PACE1: Degrelle et al. 2005; BMP4 for bone morphogenic protein-4: Cammas et al. 2005). Nevertheless, this does not mean necessarily that similar gene networks are involved in establishing early embryonic polarities in ruminant and in rodent extra-embryonic tissues. This topic awaits further studies in ruminants (I Hue, unpublished observations), but reassures us in pro- 
posing that the ovoid stage is a critical step in the transition between a spherical and a tubular shape, and also between an ICM and an epiblast developmental stage in bovine conceptuses.

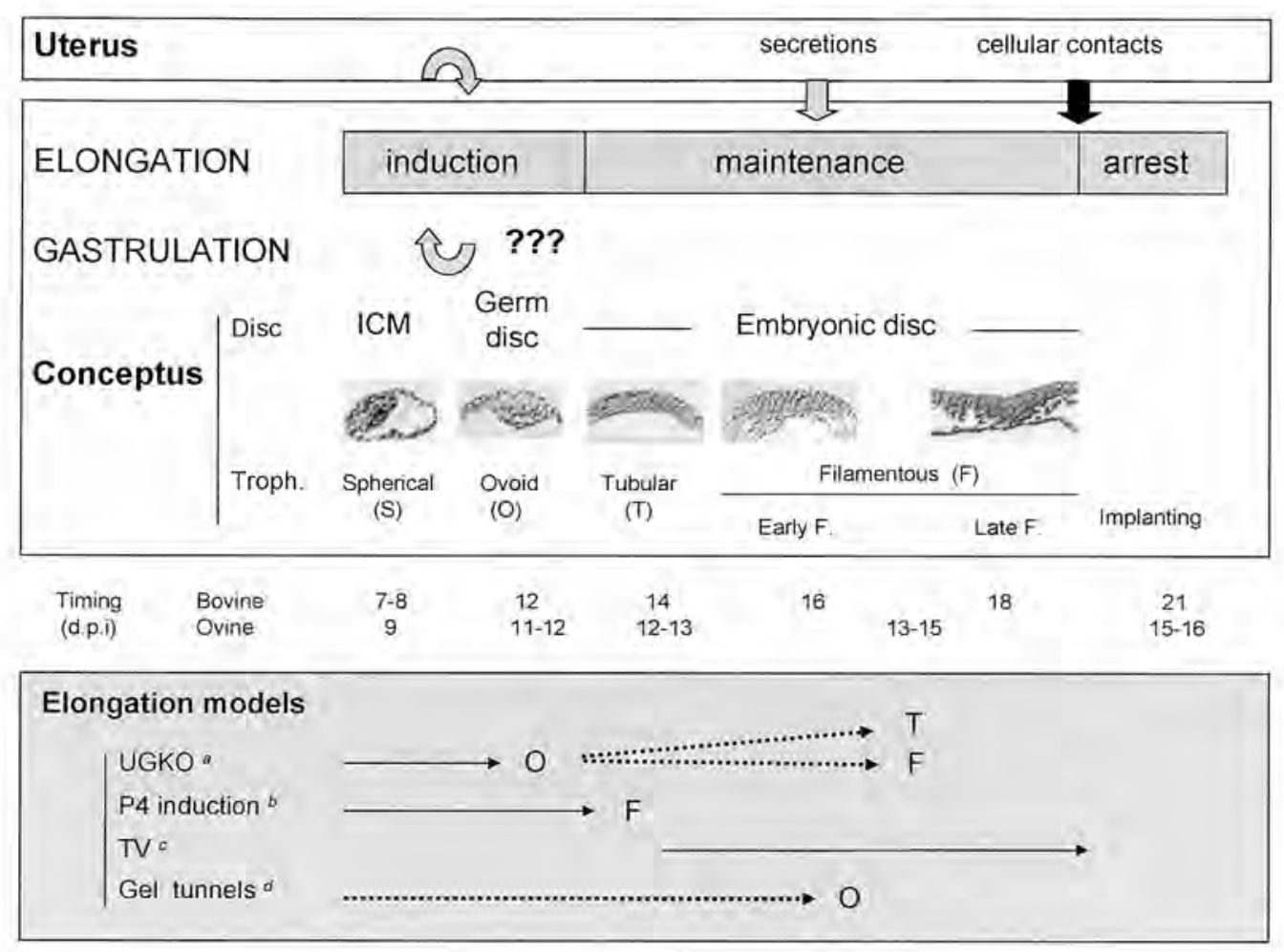

Fig. 2. From a puzzle to an integrated model? In ruminants, the elongation of the conceptus defines the exponential growth of the blastocyst as well as the evolution in its size and shape from a spherical $(S)$ to an ovoid $(O)$, a tubular $(T)$ and finally a filamentous $(F)$ form. These elongating stages also correspond to different stages of embryonic development from an inner cell mass (or ICM) to a germinal disc and finally an embryonic disc. Four main models have been established so far to study what governs the induction and maintenance of the elongation process. Among them: the UGKO model in sheep and the P4 induction model (in sheep and cow) helped analysing the induction phase ( $)$.). The excision of the disc from tubular conceptuses to get trophoblastic vesicles (or $\mathrm{T}_{+} \mathrm{V}_{+}$, in sheep and cow) demonstrated that uterine secretions maintain the elongation process once properly induced ( $\square$ ). The culture of spherical blastocysts in gel tunnels confirmed that physical constraints do not fully mimic elongation (in cows). In each model, the elongation stage reached by the blastocyst is given by the appropriate letter: $O, T$ or $F$. When most of the blastocysts reached the same stage a plain arrow is used but when they reached a stage or another, a dotted arrow is used. However, the events leading to the coordination of elongation and gastrulation have not been cleared so far in ruminants ( 1 ). On the other hand, the loose contacts formed between the conceptus and the uterus clearly mark ( ) the arrest of elongation and the onset of implantation (I). The developmental timing is scaled in days post insemination (or d.p.i) where day 0 marks the onset of oestrus. Italics refer to original reports: (a) Gray et al. 2001; 2002, (b) Satterfield et al. 2006, (c) Heyman et al. 1984; Flechon et al. 1986, (d) Vajta et al. 2004; Vejlsted et al. $2006 a$. 


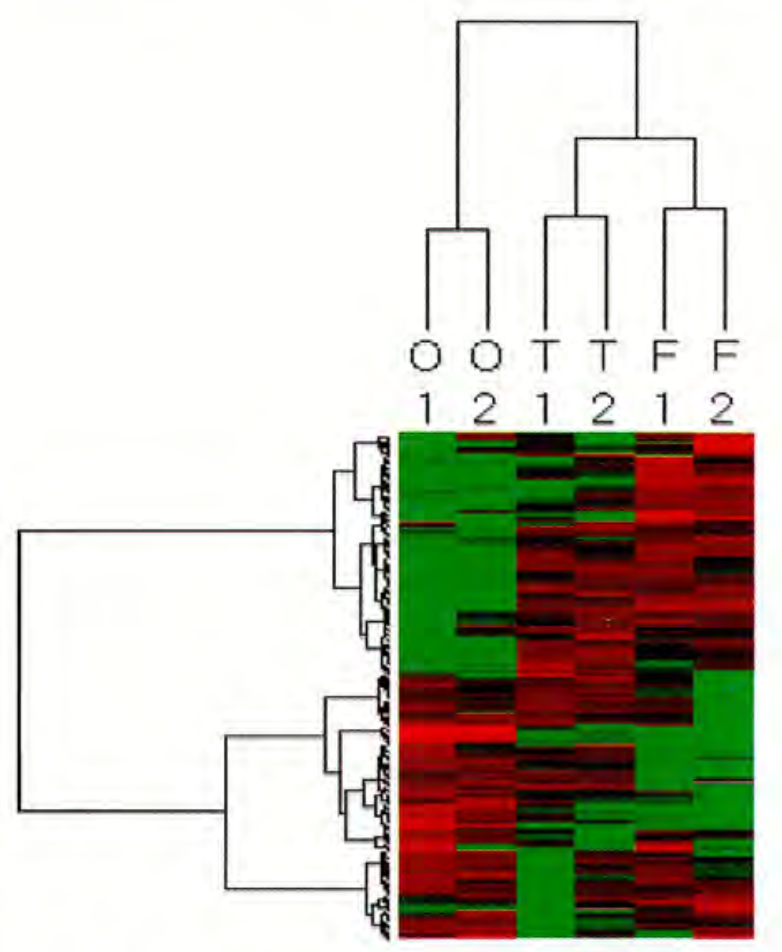

Fig. 3. Pre-gastrulating and gastrulating gene profiles for elongating extra-embryonic tissues. Hierarchical clustering of 239 genes which were differentially expressed between extra-embryonic tissues from ovoid, tubular and early filamentous conceptuses (statistically significant with AnovArray; Hennequet-Antier et al. 2005). The elongating stages were defined according to the size of the conceptuses (ovoid (O): 1-20 mm, tubular (T): 50 $60 \mathrm{~mm}$, filamentous (F): 100-150 mm) and each probe (O, T, F) corresponded to a pool of four conceptuses. Two independent probes per elongation stage (named: 1, 2) were hybridised to the $10 \mathrm{~K}$ array. This array will be described in a forthcoming paper (SA Degrelle, unpublished observations). Within the cluster, highly expressed genes are in red and low abundance genes in green. The sizes of the branches within the tree indicate distances between gene sets or elongation stages.

\section{Elongation and uterine environment}

Conceptuses of sheep and cattle produce proteins which exert an antiluteolytic effect by inhibiting uterine pulsatile release of PGF2 $\alpha$. As a consequence, continued secretion of progesterone by the corpora lutea stimulates and maintains endometrial functions necessary for growth and elongation of pre-implanting conceptuses (Thatcher et al. 1984; Spencer \& Bazer 2004). Since the first gene identified in the trophoblast encoded IFN-tau (Farin et al. 1990), endometrial genes regulated by IFN-tau have been identified in sheep and cattle together with genes induced by other secretory products of the conceptus in pregnant ruminants (Song et al. 2005; Gray et al. 2006; Klein et al. 2006). Despite the pivotal role of IFN-tau in the embryo-maternal dialog (Thatcher et al. 1989; Bazer \& Spencer 2006), other cytokines, hormones, growth factors and growth factor receptors or prostaglandins and prostaglandin receptors (Kliem et al. 1998; Burghardt et al. 2002; Wolf et al. 2003; Ashworth et al. 2006; Cammas et al. 2006), exert 
important functions. However, to go one step further in the understanding of the complex signalling pathways between the conceptus and the uterus, one now needs to analyse for temporal and spatial (cell specific) gene expression profiles both before and after elongation of the conceptus.

Reciprocally, blastocyst growth and elongation depend on uterine secretions as evidenced by increased embryonic losses in documented cases of conceptus-uterus asynchrony (Pope 1988; Barnes 2000). This has been confirmed and extended using two experimental models (Fig. 2); one that precludes uterine gland secretions, i.e, the Uterine Gland Knock Out (UGKO) ewe model (Gray et al. 2001; Gray et al. 2002) and the other that advances uterine secretory activity, i.e, the early progesterone-induced ewe (Satterfield et al. 2006) and cow (Garrett et al. 1988) models. Interestingly, 14 days after mating, UGKO ewes presented no conceptus (4 of 8 ewes), growth-retarded conceptuses ( 3 of 8 ewes) or filamentous conceptuses ( 1 of 8 ewes), versus $4 / 4$ ewes with filamentous conceptuses in untreated control ewes (Fig. 2). These results demonstrated a direct consequence of lack of uterine glands on conceptus development, that is, no uterine glands and no conceptuses, moderate gland density and retarded to normal conceptuses. On the contrary, exogenous progesterone administration 1.5 days after mating led to increased blastocyst diameters on day 9 and advanced the timing of elongation (filamentous stages on Day 12 already). Unfortunately, not much is known about conceptus development in the ewe model, but secretion of IFN-tau was advanced in cows. There remain many questions, e.g., how does a growth-retarded sheep conceptus (developed in UGKO ewes) appear morphologically when no INF-tau is present in the corresponding uterine flushes? Conversely, in the P4-induced model is the advanced elongation process perfectly similar to that for normal conceptuses? Undoubtedly, gene expression profiling studies on embryonic and extra-embryonic tissues in such situations will provide essential data on the genes or developmental cascades involved in successful uterus/conceptus cross-talk.

\section{In vitro elongation}

Mimicking the elongation process in vitro has long been a challenge, but has provided many interesting features and questions (Fig. 2). The first experimental approach was to collect in vivo elongated conceptuses at the tubular stage (sheep: Day 12; cow: Day 14) cut them into pieces on both sides of the embryonic disc, cultivate them in vitro or transfer them back in utero. In both species, it appeared that the resulting "trophoblastic vesicles" survived, but did not elongate further in vitro whereas they could elongate and produce IFN-tau during 5 day period following transfer back into a synchronous uterine environment (Heyman et al. 1984; Flechon et al. 1986). As such, it seems that the elongation process and IFN-tau secretion require the uterine environment, but not the embryonic disc (Fig. 2). However, in the absence of any additional results, one does not know whether such trophoblast elongation resembles a normal transition of tubular to filamentous conceptuses.

The second approach to initiating the elongation process in vitro was to incubate spherical blastocysts in gel tunnels containing glucose-rich medium (Vajta et al. 2004). Compared to cultures in Petri dishes where blastocysts only formed spheres of increasing diameters, cultures in gel tunnels induced a constrained elongation in most blastocysts although very few survived until Day 16 (2/67). The size of the longest blastocyst obtained was about $12 \mathrm{~mm}$ which is the size of an ovoid blastocyst developed in vivo (1-20 mm; Day 12). Nevertheless, in the few healthy-looking blastocyts (2/67), the inner cell mass had developed, a second cell layer had formed and completed development (Brandao et al. 2004), but there was no regression of the Rauber's layer and no formation of a true embryonic disc (Vejlsted et al. 2006a). Moreover, 
many blastocysts degenerated during culture, even those which grew in Petri dishes, suggesting that the medium used may not have met the metabolic needs of these blastocysts. In light of recent results concerning differential and constitutive gene expression during elongation of ruminant conceptuses, optimising a medium that can (i) sustain protein, nucleic acid, carbohydrate and lipid metabolism of the embryos and (ii) accommodate associated catabolism, seems challenging. Even more challenging are efforts in vitro to mimic the uterine environment which is just being decrypted through proteomic studies (Berendt et al, 2005).

\section{Elongation: hypotheses and open questions}

Based on the models and results presented in this review, three basic features can describe what we know about elongation: (i) it depends on uterine secretions; (ii) it is tightly coordinated with growth and differentiation of the embryonic disc; and (iii) it is not likely to be solely dependent on a physical constraint such as the shape of the uterus. This knowledge is, however, difficult to integrate in a simple model of elongation induction, maintenance and arrest. This is partly due, in our opinion, to: (i) confusion around the start point of elongation and lack of understanding of the mechanisms which induce it; (ii) absence of biological parameters to define the phases of induction or maintenance of conceptus development; and (iii) partial datasets available in vivo, in vitro and in experimental models since the uterus or the conceptus, but not both, were usually studied. To gain insights into this simple view of induction, maintenance and arrest of elongation, we will summarize what is known about each phase of the conceptus development.

Induction: After mating, uteri of UGKO ewes maintained conceptuses until Day 9 (spherical stage, $900 \mu \mathrm{m}$ ), the conceptuses could not elongate in UGKO ewes, but could in normal ewes. Also, conceptuses from normal ewes did not elongate in uteri of UGKO ewes. Therefore, the mechanism for induction of conceptus elongation is not inherent within the conceptus. However, between the onset of elongation and the parameters that define the ovoid stage: (i) a shape is defined by conceptus length that is about 1.3 times its width (Grealy et al. 1996); (ii) a specific programming of the ruminant trophoblast results in its expression of epiblast genes (Degrelle et al. 2005); (iii) an intense proliferation of the mural lineage occurs; and (iv) a gene expression profile for extra-embryonic tissues which define pre-gastrulating features. The question is what do the uterine secretions induce? Do they interfere with or influence embryonic-extraembryonic interactions in any way?

Maintenance: Similar to the situation of normal sheep blastocysts in UGKO ewes, trophoblastic vesicles derived at tubular stages do not elongate in vitro, but do so in vivo, indicating that induction of conceptus elongation depends on uterine signalling. However, we do not know which components of uterine secretions induce the elongation process or which components of these secretions maintain the conceptus. Do they maintain (i) an elongated shape which does not result solely from physical constraints imposed by the uterine wall since equine conceptuses (though confined as well in long uterine horn) remain spherical from Day 6 to Day 22 (reviewed in Allen 2001) (ii) an ongoing proliferation process (iii) ongoing IFN-tau secretion and/or (iv) a gastrulating signature in tubular and filamentous extra-embryonic tissues?

Arrest: We have known for decades that elongation stops at apposition, the onset of the implanting process (Guillomot 1995; Spencer èt al. 2004). However, embryonic development does not stop concomitantly, since neural folds and somites appear at that time as if this phase of elongation arrest initiates another stage to achieve synchrony between pre-placental and fetal tissues. These events, however, are outside the focus of this review. 
Defining similarities and differences between elongating processes in conceptuses from sheep, cow and pig could help us understand the basic core mechanisms responsible for elongation of conceptuses. Unfortunately, this has not been studied so far although a number of reports on molecular data are available for pigs (Yelich et al. 1997b; Wilson et al. 2000; Ross et al. 2003; Blomberg et al. 2005; Lee et al. 2005). At present, we have some pieces of the elongation puzzle, but must continue searching for the missing cues until an integrated model can be developed and validated.

\section{Conclusions}

Although known for decades, mechanisms responsible for elongation of conceptuses are far from being understood. This is likely due to: i) the numerous interactions with the uterus and the embryonic disc so that only well synchronised processes give rise to a successful pregnancy; ii) the complexity of the process: early processes and late processes which might be distinct but interdependent on each other; iii) cross-talk between cell layers which compose the extra-embryonic tissues; and iv) the inability, to date, to mimic or dissect this complex process in vitro.

\section{Acknowledgments}

The authors gratefully acknowledge A. Hernandez", R. Everts,, H. Lewini, C. Tian ${ }^{\mathrm{b}}$ and J. Yang ${ }^{\mathrm{b}}$ for their contribution to the construction of the bovine10K array ('University of Urbana, Illinois, USA; b University of Storrs, Connecticut, USA), the UCEA from Bressonvilliers for the access to in vivo developed bovine conceptuses and M. Guillomot (INRA, VMR1198) for helpful discussions and critical reading of the manuscript.

\section{References}

Allen WR 2001 Fetomaternal interactions and influences during equine pregnancy. Reproduction 121513 527.

Anderson LL 1978 Growth, protein content and distribution of early pig embryos. The Anatomical Record 190 143-153.

Ashworth MD, Ross JW, Hu J, White FJ, Stein DR, Desilva U, Johnson GA, Spencer TE \& Geisert RD 2006 Expression of porcine endometrial prostaglandin synthase during the estrous cycle and early pregnancy, and following endocrine disruption of pregnancy. Biology of Reproduction 74 1007-1015.

Barnes FL 2000 The effects of the early uterine environment on the subsequent development of embryo and fetus. Theriogenology 53 649-658.

Bauersachs S, Ulbrich SE, Gross K, Schmidt SEM, Meyer HHD, Wenigerkind $H$, Vermehren $M$, Sinowatz F, Blum H \& Wolf E 2006 Embryo-induced transcriptome changes in bovine endometrium reveal species-specific and common molecular markers of uterine receptivity. Reproduction 132319 331.

Bazer FW \& Spencer TE 2006 Methods for studying interferon tau stimulated genes. Methods in Molecu- lar Medicine 122 367-380.

Beck S, Le Good JA, Guzman M, Ben Haim N, Roy K, Beermann F \& Constam DB 2002 Extraembryonic proteases regulate Nodal signalling during gastrulation. Nature Cell Biology 4 981-985.

Berendt FJ, Frohlich T, Schmidt SE, Reichenbach HD, Wolf E \& Arnold GI 2005 Holistic differential analysis of embryo-induced alterations in the proteome of bovine endometrium in the preattachment period. Proteomics 5 2551-2560.

Betteridge KJ \& Flechon JE 1988 The anatomy and physiology of pre-attachment bovine embryos. Theriogenology 29 155-187.

Blomberg le A, Long EL, Sonstegard TS, Van Tassell CP, Dobrinsky JR \& Zuelke KA 2005 Serial analysis of gene expression during elongation of the periimplantation porcine trophectoderm (conceptus). Physiological Genomics 20 188-194.

Blomberg le A, Garrett WM, Guillomot M, Miles JR, Sonstegard TS, Van Tassell CP \& Zuelke KA 2006 Transcriptome profiling of the tubular porcine conceptus identifies the differential regulation of growth and developmentally associated genes. Molecular Reproduction and Development 73 1491-1502. 
Brandao DO, Maddox-Hyttel P, Lovendahl P, Rumpf R, Stringfellow D \& Callesen H 2004 Post hatching development: a novel system for extended in vitro culture of bovine embryos. Biology of Reproduction 71 2048-2055.

Burghardt RC, Johnson GA, Jaeger LA, Ka H, Garlow IE, Spencer TE \& Bazer FW 2002 Integrins and extracellular matrix proteins at the maternal-fetal interface in domestic animals. Cells, Tissues, Organs 172 202-217.

Cammas L, Reinaud P, Dubois O, Bordas N, Germain G \& Charpigny G 2005 Identification of differentially regulated genes during elongation and early implantation in the ovine trophoblast using complementary DNA array screening. Biology of Reproduction 72 960-967.

Cammas L, Reinaud P, Bordas N, Dubois O, Germain G \& Charpigny G 2006 Developmental regulation of prostacyclin synthase and prostacyclin receptors in the ovine uterus and conceptus during the periimplantation period. Reproduction $131917-927$.

Chakrabarty A, Green JA \& Roberts RM 2006 Origin and evolution of the TKDP gene family, Gene 373 35-43.

Chang MC 1952 Development of bovine blastocyst with a note on implantation. The Anatomical Record 113 143-161.

Degrelle SA, Campion E, Cabau C, Piumi F, Reinaud P, Richard C, Renard JP \& Hue I 2005 Molecular evidence for a critical period in mural trophoblast development in bovine blastocysts. Developmental Biology 288 448-460.

Dore JJ, Roberts MP \& Godkin JD 1994 Early gestational expression of retinol-binding protein mRNA by the ovine conceptus and endometrium. Molecular Reproduction and Development 38 24-29.

Dunne LD, Diskin MG \& Sreenan JM 2000 Embryo and foetal loss in beef heifers between day 14 of gestation and full term. Animal Reproduction Science 58 39-44.

Farin CE, Imakawa K, Hansen TR, McDonnell JJ, Murphy CN, Farin PW \& Roberts RM 1990 Expression of trophoblastic interferon genes in sheep and cattle. Biology of Reproduction 43 210-218.

Flechon JE, Guillomot M, Charlier M, Flechon B \& Martal J 1986 Experimental studies on the elongation of the ewe blastocyst. Reproduction, Nutrition. Development 26 1017-1024.

Flechon JE, Degrouard J \& Flechon B 2004 Gastrulation events in the prestreak pig embryo: ultrastructure and cell markers. Genesis 38 13-25.

Garrett JE, Geisert RD, Zavy MT, Morgan GL 1988 Evidence for maternal regulation of early conceptus growth and development in beef cattle. Journal of Reproduction and Fertility 84 437-446.

Geisert RD, Brookbank JW, Roberts RM \& Bazer FW 1982 Establishment of pregnancy in the pig: II. Cellular remodeling of the porcine blastocyst during elongation on day 12 of pregnancy. Biology of Reproduction 27 941-955.

Goff AK 2002 Embryonic signals and survival. Repro- duction in Domestic Animals 37 133-139.

Gray CA, Taylor KM, Ramsey WS, Hill JR, Bazer FW, Bartol FF \& Spencer TE 2001 Endometrial glands are required for preimplantation conceptus elongation and survival. Biology of Reproduction 641608 1613.

Gray CA, Burghardt RC, Johnson GA, Bazer FW \& Spencer TE 2002 Evidence that absence of endometrial gland secretions in uterine gland knockout ewes compromises conceptus survival and elongation. Reproduction 124 289-300.

Gray CA, Abbey CA, Beremand PD, Choi Y, Farmer IL, Adelson DL, Thomas TL, Bazer FW \& Spencer TE 2006 Identification of endometrial genes regulated by early pregnancy, progesterone, and interferon tau in the ovine uterus. Biology of Reproduction 74 383-394.

Grealy M, Diskin MG \& Sreenan JM 1996 Protein content of cattle oocytes and embryos from the twocell to the elongated blastocyst stage at day 16. Journal of Reproduction and Fertility 107 229-233.

Green JA, Xie S, Quan X, Bao B, Gan X, Mathialagan N, Beckers JF \& Roberts RM 2000 Pregnancy-associated bovine and ovine glycoproteins exhibit spatially and temporally distinct expression patterns during pregnancy. Biology of Reproduction 62 16241631 ,

Greenstein JS, Murray RW \& Foley RC 1958 Observations on the morphogenesis and histochemistry of the bovine preattachment placenta between 16 and 33 days of gestation. The Anatomical Record 132 321-341.

Guillomot M 1995 Cellular interactions during implantation in domestic ruminants. Journal of Reproduction and Fertility, Supplement 49 39-51.

Guillomot M, Turbe A, Hue I \& Renard JP 2004 Staging of ovine embryos and expression of the T-box genes Brachyury and Eomesodermin around gastrulation. Reproduction 127 491-501.

Guzman-Ayala M, Ben-Haim N, Beck S \& Constam DB 2004 Nodal protein processing and fibroblast growth factor 4 synergize to maintain a trophoblast stem cell microenvironment. Proceedings of the National Academy of Sciences of the United States of America 101 15656-15660.

Hennequet-Antier C, Chiapello $H$, Piot $K$, Degrelle $S$, Hue I, Renard JP, Rodolphe F \& Robin S 2005 AnovArray: a set of SAS macros for the analysis of variance of gene expression data. BMC Bioinformatics 6150 .

Heyman V, Camous S, Fevre J, Meziou W \& Martal J 1984 Maintenance of the corpus luteum after uterine transfer of trophoblastic vesicles to cyclic cows and ewes. lournal of Reproduction and Fertility 70 533-540.

Hue I, Renard JP \& Viebahn C 2001 Brachyury is expressed in gastrulating bovine embryos well ahead of implantation. Development Genes and Evolution 211 157-159.

Hughes AL, Green JA, Piontkivska H \& Roberts RM 2003 Aspartic proteinase phylogeny and the origin 
of pregnancy-associated glycoproteins. Molecular Biology and Evolution 20 1940-1945.

Idkowiak J, Weisheit G, Plitzner J \& Viebahn C 2004 Hypoblast controls mesoderm generation and axial patterning in the gastrulating rabbit embryo. Development Genes and Evolution 214 591-605.

Imakawa K, Chang KT \& Christenson RK 2004 Preimplantation conceptus and maternal uterine communications: molecular events leading to successful implantation. The Journal of Reproduction and Development $50 \quad 155-169$.

Klein C, Bauersachs S, Ulbrich SE, Einspanier R, Meyer HH, Schmidt SE, Reichenbach HD, Vermehren $M$, Sinowatz F, Blum H, Wolf E 2006 Monozygotic twin model reveals novel embryo-induced transcriptome changes of bovine endometrium in the preattachment period. Biology of Reproduction 74 253-264.

Kliem A, Tetens F, Klonisch T, Grealy M \& Fischer B 1998 Epidermal growth factor receptor and ligands in elongating bovine blastocysts. Molecular Reproduction and Development 51 402-412.

Klisch K, De Sousa NM, Beckers JF, Leiser R \& Pich A 2005 Pregnancy associated glycoprotein-1, $-6,-7$, and -17 are major products of bovine binucleate trophoblast giant cells at midpregnancy. Molecular Reproduction and Development 71 453-460.

Lee SH, Zhao SH, Recknor JC, Nettleton D, Orley S, Kang SK, Lee BC, Hwang WS \& Tuggle CK 2005 Transcriptional profiling using a novel cDNA array identifies differential gene expression during porcine embryo elongation. Molecular Reproduction and Development 71 129-139.

Maclean JA, 2nd, Chakrabarty A, Xie S, Bixby JA, Roberts RM \& Green JA 2003 Family of Kunitz proteins from trophoblast: expression of the trophoblast Kunitz domain proteins (TKDP) in cattle and sheep. Molecular Reproduction and Development 65 30-40.

MacLean JA, 2nd, Roberts RM \& Green JA 2004 Atypical Kunitz-type serine proteinase inhibitors produced by the ruminant placenta. Biology of Reproduction 71 455-463.

Meijer HA, Van De Pavert SA, Stroband HW \& Boerjan ML 2000 Expression of the organizer specific homeobox gene goosecoid (gsc) in porcine embryos. Molecular Reproduction and Development 55 1-7.

Pope WF 1988 Uterine asynchrony: a cause of embryonic loss. Biology of Reproduction 39 999-1003.

Richardson L, Torres-Padilla ME \& Zernicka-Goetz M 2006 Regionalised signalling within the extraembryonic ectoderm regulates anterior visceral endoderm positioning in the mouse embryo. Mechanisms of Development 123 288-296.

Roberts RM, Ezashi T \& Das P 2004 Trophoblast gene expression: transcription factors in the specification of early trophoblast. Reproductive Biology and Endocrinology 247.

Ross JW, Ashworth MD, Hurst AG, Malayer JR \& Geisert RD 2003 Analysis and characterization of differential gene expression during rapid tropho- blastic elongation in the pig using suppression subtractive hybridization. Reproductive Biology and Endocrinology 123.

Rossant J 2004 Lineage development and polar asymmetries in the peri-implantation mouse blastocyst. Seminars in Cell \& Developmental Biology 15573 581.

Satterfield MC, Bazer FW \& Spencer T 2006 Progesterone regulation of preimplantation conceptus growth and galectin 15 (LGALS15) in the ovine uterus. Biology of Reproduction 75 289-296.

Song G, Spencer TE \& Bazer FW 2005 Cathepsins in the ovine uterus: regulation by pregnancy, progesterone, and interferon tau. Endocrinology 1464825 4833.

Spencer TE \& Bazer FW 2004 Uterine and placental factors regulating conceptus growth in domestic animals. Journal of Animal Science 82 E-Suppl E4-13.

Spencer TE, Johnson GA, Bazer FW \& Burghardt RC 2004 Implantation mechanisms: insights from the sheep. Reproduction 128 657-668.

Thatcher WW, Bartol FF, Knickerbocker JJ, Curl JS, Wolfenson D, Bazer FW \& Roberts RM 1984 Maternal recognition of pregnancy in cattle. Journal of Dairy Science 67 2797-2811.

Thatcher WW, Hansen PJ, Gross TS, Helmer SD, Plante C \& Bazer FW 1989 Antiluteolytic effects of bovine trophoblast protein-1. Journal of Reproduction and Fertility, Supplement 37 91-99.

Trout WE, McDonnell JJ, Kramer KK, Baumbach GA \& Roberts RM 1991 The retinol-binding protein of the expanding pig blastocyst: molecular cloning and expression in trophectoderm and embryonic disc. Molecular Endocrinology 5 1533-1540.

Ushizawa K, Herath CB, Kaneyama K, Shiojima S, Hirasawa A, Takahashi T, Imai K, Ochiai K, Tokunaga T, Tsunoda Y, Tsujimoto G, Hasizume K 2004 cDNA microarray analysis of bovine embryo gene expression profiles during the pre-implantation period. Reproductive Biology and Endocrinology 277.

Vajta G, Alexopoulos NI \& Callesen H 2004 Rapid growth and elongation of bovine blastocysts in vitro in a three-dimensional gel system. Theriogenology 62 1253-1263.

van de Pavert SA, Schipper $\mathbf{H}$, de Wit AA, Soede NM, van den Hurk R, Taverne MA, Boerian ML \& Stroband HW 2001 Comparison of anterior-posterior development in the porcine versus chicken embryo, using goosecoid expression as a marker. Reproduction, Fertility and Development 13177 185.

Vejlsted M, Avery B, Schmidt M, Greve T, Alexopoulos N \& Maddox-Hyttel P 2005 Ultrastructural and immunohistochemical characterization of the bovine epiblast. Biology of Reproduction 72 678-686.

Vejlsted M, Du Y, Vajta G \& Maddox-Hyttel P 2006a Post-hatching development of the porcine and bovine embryo-defining criteria for expected development in vivo and in vitro. Theriogenology 65 153-165. 
Vejlsted M, Offenberg $H$, Thorup F \& Maddox-Hyttel P 2006b Confinement and clearance of OCT4 in the porcine embryo at stereomicroscopically defined stages around gastrulation. Molecular Reproduction and Development 73 709-718.

Wilson ME, Sonstegard TS, Smith TP, Fahrenkrug SC \& Ford SP 2000 Differential gene expression during elongation in the preimplantation pig embryo. Genesis 26 9-14.

Wintenberger-Torres S \& Flechon JE 1974 Ultrastructural evolution of the trophoblast cells of the preimplantation sheep blastocyst from day 8 to day 18 . Journal of Anatomy 118 143-153.

Wolf E, Arnold GJ, Bauersachs S, Beier HM, Blum $\mathrm{H}$, Einspanier R, Frohlich T, Herrler A, Hiendleder S, Kolle S, Prelle K, Reichenbach HD, Stojkovic M, Wenigerkind H, Sinowatz F 2003 Embryo-maternal communication in bovine - strategies for deciphering a complex cross-talk. Reproduction in Domestic Animals 38 276-289.
Xavier F, Lagarrigue S, Guillomot M \& GaillardSanchez I 1997 Expression of c-fos and jun protooncogenes in ovine trophoblasts in relation to interferon-tau expression and early implantation process. Molecular Reproduction and Development 46 127-137.

Yelich JV, Pomp D \& Geisert RD 1997a Detection of transcripts for retinoic acid receptors, retinol-binding protein, and transforming growth factors during rapid trophoblastic elongation in the porcine conceptus. Biology of Reproduction 57 286-294.

Yelich JV, Pomp D \& Geisert RD 1997b Ontogeny of elongation and gene expression in the early developing porcine conceptus. Biology of Reproduction 57 1256-1265. 